\title{
STANDARDS FOR NURSING AGENCIES IN SOUTH AFRICA
}

\author{
Marie Muller \\ DCur \\ Professor of Nursing, Department of Nursing Science, Rand Afrikaans University
}

\begin{abstract}
The purpose with this research is to formulate standards for nursing agencies in South Africa. The researcher was approached by the Association of Nursing Agencies in South Africa (ANASA) to assist them with the development of a quality/accreditation programme for nursing agencies. An exploratory and descriptive quantitative research design was employed. A structured two-phase model was utilised consisting of a developmental and a quantification phase for the development of standards and criteria. A series of four workshops were held during which a framework for the standards was developed, draft standards were formulated, refined and exposed to a quantification phase where the Content Validity Index (CVI) of the standards and criteria were determined in relation to relevance, clarity and implementation in reality. The representatives at these workshops consisted of nursing agency managers $(N=22)$ who hold membership with ANASA and attended their meetings. A high CVI rating was obtained with regard to the relevance and clarity of the standards and criteria. Some standards and many criteria are not yet being implemented in the nursing agencies resulting in a lower CVI rating in this regard. The final set of standards was exposed to a group of stakeholders for final validation purposes, by means of sufficient consensus debate. The standards and criteria were reflected in an evaluation guide/instrument and pilot tested by means of a moc survey in a nursing agency in Gauteng. It is recommended that these standards and criteria, as reflected by means of an evaluation guide, be utilised by the nursing agencies and that the South African Nursing Council use them for licensing and continuous accreditation of nursing agencies in South Africa. Due to the fact that the participants were ANASA members, other nursing agencies were excluded and national representation of the participants/validators can therefore not be claimed.
\end{abstract}

\section{UITTREKSEL}

Die doel met hierdie navorsing is om standaarde vir verpleegagentskappe in Suid-Afrika te formuleer. Die navorser is deur die vereniging van verpleegagentskappe in Suid-Afrika (Association of Nursing Agencies in South Africa: ANASA) genader om hulle behulpsaam te wees met die ontwikkeling van 'n gehaltel akkrediteringsprogram vir verpleegagentskappe. 'n Verkennende, beskrywende kwantitatiewe navorsingsontwerp is nagevolg. 'n Gestruktureerde twee-fase model is benut, bestaande uit 'n ontwikkelingsen kwantifiseringsfase vir die ontwikkeling van die standaarde en kriteria. ' $n$ Reeks van vier werkswinkels is gehou waartydens 'n konseptuele raamwerk vir die standaarde ontwikkel is, voorlopige standaarde opgestel, verfyn en aan 'n gekwantifiseerde fase onderwerp is waartydens die inhoudsgeldigheidsindeks ten opsigte van relevansie, duidelikheid en realiteit bepaal is. Die verteenwoordigers by hierdie werkswinkels het uit verpleegagentskapbestuurders $(N=22)$ bestaan wat lede van ANASA is en hul vergaderings bygewoon het. ' $n$ Hoë inhoudsgeldigheidsindeks ten opsigte van relevansie en duidelikheid is verkry. Sommige standaarde 
en heelwat kriteria word nog nie in die verpleegagentskappe toegepas nie met 'n gevolglike lae inhoudsgeldigheidsindeks wat vir realiteit bereik is. Die finale stel standaarde en kriteria is aan rolspelers blootgestel vir die finale validering van die standaarde by wyse van toereikende konsensusdebat. Hierdie standaarde is in die vorm van 'n evaluasie-instrument gereflekteer en by wyse van 'n loodsstudie in 'n agentskap in Gauteng uitgetoets. Daar word aanbeveel dat die standaarde en kriteria, wat in die vorm van ' $n$ evaluasiegids gereflekteer word, deur verpleegagentskappe benut word en dat die Suid-Afrikaanse Raad op Verpleging die standaarde vir lisensiëring en volgehoue akkreditering van verpleegagentskappe in SuidAfrika gebruik. Weens die feit dat die deelnemers/valideerders ANASA lede is, is ander verpleegagentskappe uitgesluit en kan die navorser nie aanspraak op nasionale verteenwoordiging maak nie.

\section{INTRODUCTION}

The nursing service manager is accountable for the provision of quality nursing care to the patient in the health care delivery service, as well as for goaldirected and cost-effective management of the nursing service. The nursing management outputs should be achieved in the most cost-effective manner without jeopardising the quality of care. An adequate nursing staff establishment is therefore of paramount importance. A shortage of permanent nursing staff is often due to sick leave or absenteeism, a sudden increase in the workload within a particular unit, or due to the working/ employment pattern of nurses in a specific area. Nursing agencies supply nursing staff directly to the patient or to a health care service. The nursing agencies therefore play an important role in the provision of nursing staff in South Africa, not only as a back-up system for health care services, but also as a method to render cost-effective nursing care, provided that quality is ensured. As any other business, the nursing agency strives towards excellence. This article focuses on standards for nursing agencies in South Africa to reflect the dimensions and criteria of excellence.

Quality refers to the characteristics/attributes of excellence (Muller, 1998:237) within a given service; but excellence has to be defined and described by means of standards and criteria in accordance with the legal obligations and expectations of the relevant stakeholders. Quality assurance/improvement is a formal and continuous process where standards are set, performance is measured and evaluated against these standards, followed by remedial action to counteract the problems or poor performance outcomes (Muller, 1998:242). Standards and subsequent criteria for nursing agencies, reflected in the form of an evaluation instrument, need to be formulated as nursing agencies play a significant role in clinical nursing service delivery in South Africa today. As there are no standards for nursing agencies in South Africa available, they need to be formulated. These standards can be utilised by the nursing agencies for empowerment and self-evaluation purposes and/ or by an external peer group system for accreditation purposes.

A nursing agency standard is a description of the expected performance (structure, process or outcome) of the nursing agency. These standards should focus on the quality of nursing agency management. The quality of clinical nursing/ midwifery care can be evaluated by means of another set of standards and criteria.

The following research question is applicable: how should excellence within a nursing agency in South Africa be described/reflected? The purpose with this research is to formulate standards for nursing agencies in South Africa.

\section{TERMINOLOGY}

\section{Standard}

A standard is a description of the expected man- 
agement performance (structure, process or outcome) of the nursing agency in South Africa.

\section{Nursing Agency}

A nursing agency means a business which supplies registered nurses or midwives or enrolled nurses or nurse auxiliaries to a person, organisation or institution, whether for gain or not and whether in conjunction with any other service rendered by such business or not (South Africa, 1978, clause 1(ix), as amended).

\section{RESEARCH DESIGN}

An exploratory and descriptive quantitative research design (Burns \& Grove, 1993) was utilised within the context of nursing agencies in South Africa. The researcher was approached by the Association of Nursing Agencies in South Africa (ANASA) in October 1999 with the request to assist them in the development of a quality/accreditation programme for nursing agencies. Although standards for nursing agencies had been formulated and published (Coetzee \& Muller, 1995:17-25), the members of ANASA were of the opinion that, in the light of transformation in South Africa, the process had to be initiated again to ensure ownership of these standards by all the stakeholders. Standard formulation is based on the structured two-phase method described by Muller (1990:49-55) and Lynn (1986) consisting of the developmental and quantification phases. Standards are conceptualised, drafted and debated by domain experts during the developmental phase. The content validity of the standards are determined during the quantification phase by exposing the standards and criteria for final validation to the domain experts and determining the Content Validity Index (CVI) of each standard and subsequent criteria (Lynn, 1986; Muller, 1990:4950; Muller, in Booyens, 1998:617-618).

A series of workshops $(\mathrm{N}=4)$ was utilised as the method of data collection and validation of the standards by means of consensus debate, decisionmaking and a Content Validity Index rating of the standards. The final set of standards were exposed to representatives at a stakeholder workshop to include members of ANASA, the regulatory body, panel members, nurse academics and the nursing service managers contracting nursing agencies to represent the client. The final standards and criteria, reflected in the form of an evaluation guide, were pilot tested by means of a "moc survey" at a nursing agency in Gauteng. A description of the developmental and quantification phases is presented.

\section{Developmental phase}

An initial exploratory meeting was held between the researcher/consultant and members $(\mathrm{N}=25)$ of ANASA in November 1999. This was followed by a workshop in January 2000 where the framework for the standards was developed by the attendants $(\mathrm{N}=26)$. This framework related to the following: agency strategic framework, licensing, general governance/management, financial management, contracts, affiliation and co-operation, policies and procedures, communication, human resource management, risk management, statistics and record keeping, quality improvement and marketing of the agency. Sections of this framework were divided between four working groups who drafted the first set of standards and criteria. These were debated by an elected core group of ANASA members and the consultant on the 13th of March 2000. The consultant refined the first set of standards/criteria in accordance with the conceptual framework (second draft of standards) and prepared them for a quantified validation session/debate on the $22 \mathrm{nd}$ of June 2000.

\section{Quantification phase}

These standards/criteria (second draft) were validated by 22 nursing agency members (quantification phase of standard development). A 
Content Validity Index (CVI) was determined during this phase (see description on validity and reliability, as well as data-analysis) after which the standards were refined again (third draft) and exposed to the stakeholder workshop for final validation by means of a sufficient consensus debate on the $30^{\text {th }}$ of August 2000.

\section{Population and sampling}

The population consists of all the registered nursing agencies in South Africa $(\mathrm{N}=195)$ at the time of the first meeting/consultative session with the researcher in 1999. The accessible population was determined as the nursing agencies that are members of ANASA $(\mathrm{N}=45)$. Accessibility is enhanced by the fact that these nursing agencies are organised and meet regularly and act as a powerbase in the interest of patient care, service delivery and the nursing agencies themselves. A purposive non-probability sampling method (Burns \& Grove, 1993:66) was utilised, based on the following inclusion criteria in relation to domain experts:

ANASA members attending the General Annual Meeting of ANASA and subsequent standard formulation workshops, based upon an open invitation by the ANASA management.

- ANASA Executive Committee Members that were elected by the members to represent them and act as the leadership within the mandate given by their membership (second set of draft standards).

- Invited nursing service managers from hospitals that were determined by the ANASA members as significant clients to validate the final (third) set of standards on 30 August 2000.

- Panel members (agency nursing practitioners) invited by ANASA to participate in the final validation of standards on 30 August 2000.

- An invitation to the South African Nursing Council to attend the final validation workshop on 30 August 2000.

- Two nurse academics specialising in nursing service management and acquainted with the process of standard formulation.

- The convenor of the Professional Matters Committee at DENOSA to attend all the workshops and to act as an independent researcher.

The sample realisation and distribution, as well as justification of the domain expertise and the representivity of validators, are reflected in tables one to five.

Table 1: Distribution of posts held by the participants/validators and their main responsibilities during the developmental and quantification phases $(\mathrm{N}=22)$

\begin{tabular}{|l|l|l|l|}
\hline Post & N & Responsibility & N \\
\hline $\begin{array}{l}\text { General manager of the } \\
\text { agency }\end{array}$ & 17 & $\begin{array}{l}\text { Overall management } \\
\text { of the agency }\end{array}$ & 17 \\
\hline Nursing Serwice Manager & 4 & $\begin{array}{l}\text { Nursing serwice } \\
\text { manager }\end{array}$ & 4 \\
\hline Public Relations Officer & 1 & Public relations & 1 \\
\hline TOTAL & 22 & TOTAL & 22 \\
\hline
\end{tabular}

Table 2: Distribution of province represented by the participants during the developmental and quantification phases $(\mathrm{N}=22)$

\begin{tabular}{|l|l|}
\hline Province & N \\
\hline Eastem Cape & 2 \\
\hline Free State & 1 \\
\hline Gauteng & 14 \\
\hline KwaZulu Natal & 2 \\
\hline North Wu'est & 1 \\
\hline Western Cape & 2 \\
\hline
\end{tabular}

Table 3: Distribution of highest qualifications of validators during the developmental and quantification phases $(\mathrm{N}=22)$

\begin{tabular}{|l|l|}
\hline Qualification & N \\
\hline Diploma & 14 \\
\hline B-degree & 6 \\
\hline Masters degree & 2 \\
\hline TOTAL & 22 \\
\hline
\end{tabular}

Table 4: Years of experience (validators) within a nursing agency $(\mathrm{N}=22)$

\begin{tabular}{|l|l|}
\hline $\begin{array}{l}\text { Years of experience within a } \\
\text { nursing agency }\end{array}$ & $\mathbf{N}$ \\
\hline $0-5$ & 17 \\
\hline $6-10$ & 3 \\
\hline $11-15$ & 1 \\
\hline $16>$ & 1 \\
\hline TOTAL & 22 \\
\hline
\end{tabular}


Table 5: Distribution of stakeholders during final consensus debate

\begin{tabular}{|l|l|l|}
\hline Stakeholder & Invited & Attended \\
\hline Nursing Serwice Managers (hospitals) & 13 & 6 \\
\hline Nursing Agencies & 15 & 14 \\
\hline $\begin{array}{l}\text { Panel members (agency nursing } \\
\text { practitioners) }\end{array}$ & 5 & 3 \\
\hline South African Nursing Council & 2 & 0 \\
\hline Nurse academics & 2 & 1 \\
\hline DENOSA & 1 & 1 \\
\hline TOTAL & 38 & 25 \\
\hline
\end{tabular}

\section{Validity and reliability}

Content validity of the standards is based on the conceptual framework that reflects the legislative, professional and business management dimensions. Content validity was further ensured by utilising the two-phase structured model for standard formulation (Lynn, 1986; Muller, 1990). The principle of sufficient consensus by the participants during the developmental phase workshops was also applied (Lynn, 1986:383). Determination of the Content Validity Index (CVI) of each standard and subsequent criteria was executed by requesting an individual rating by the participants during the validation workshop in June 2000. Finally, the standards were debated and verbally verified at the last meeting in Pretoria (August 2000) by representatives of all the stakeholders (see table five). Pilot testing of the standards by means of a "moc survey" by the researcher and three members of ANASA in November 2000, was lastly conducted at a nursing agency who volunteered to be included in the pilot testing.

The following control measures were applied to ensure reliability of the standards:

Selection of participants during the developmental and quantification phases to reflect domain expertise (see tables one, three and four).

- Selection of participants (validators) to ensure representivity of all stakeholders during the final debate (see table five).

- Each participant was given equal opportunity to participate in the debates during both the developmental and quantification phases.
Quantification of the Content Validity Index during the quantification phase in relation to the relevance, clarity and logical coherence of the standards, as well as the reflection of reality in respect of the existing situation within the nursing agencies.

\section{Data-analysis}

Biographical data on the participants/validators during the quantification phase was collected to confirm the expertise and representation of the participants. A Content Validity Index (CVI) is determined during the quantification phase. The domain experts (nursing agency managers) were requested to prepare, debate and rate (3) the standards/criteria as follows:

- Relevance: do these standards/criteria reflect the main business of a nursing agency? Can we expect nursing agencies to comply with these standards and criteria as the ideal situation in respect of the minimum requirements? Have we covered everything? Have we met all your expectations/requirements as a service provider?

- Clarity/logical coherence: are the standards/ criteria formulated in a clear and understandable manner? If not - please come with suggestions for re-formulation or any additions. Is the order of the presentation acceptable or do you want any rearrangements?

- Reality: does this reflect your existing reality? Are these standards/criteria already in place within your nursing agency?

A descriptive frequency distribution was analysed and the mean "yes" rating ( $\mathrm{N}=22$ validators) of each standard and criterion was determined which is reflected as the CVI. A standard and criterion should obtain a CVI of at least 18 to reflect sufficient consensus and to therefore be declared as valid (refer to table six for the mean CVI obtained for the standards). The CVI rating of 18 was 
determined in accordance with the principles suggested by Lynn (1986).

\section{Table 6: Distribution of the CVI obtained for the standards $(\mathrm{N}=22)$}

\begin{tabular}{|c|c|c|c|}
\hline Standard & Relevance & Clarity & Reality \\
\hline $\begin{array}{l}\text { The nursing agency is managed as a business enterprise } \\
\text { ensuring quality nursing/midwife ry serwice deliwery to the } \\
\text { clients }\end{array}$ & 22 & 22 & 13 \\
\hline $\begin{array}{l}\text { The nursing agency responsible for temporary or } \\
\text { permanent placements is appropriat ely licensed with the } \\
\text { regulatory bodies }\end{array}$ & 22 & 22 & 22 \\
\hline $\begin{array}{l}\text { The nursing agency is managed in accordance with the } \\
\text { standards of good business governance }\end{array}$ & 22 & 22 & 19 \\
\hline $\begin{array}{l}\text { The financial manager/director is responsible for the } \\
\text { areparation and integrity of financial statements }\end{array}$ & 22 & 22 & 22 \\
\hline $\begin{array}{l}\text { There is evidence of contractual agreements between the } \\
\text { Nursing Agency and office staff, panel members, as well as } \\
\text { clients and other relewant stakeholders }\end{array}$ & 22 & 22 & 22 \\
\hline $\begin{array}{l}\text { The agency seeks affiliation and co-operation with relevant } \\
\text { organisations for the improvement of service delivery }\end{array}$ & 22 & 22 & 18 \\
\hline $\begin{array}{l}\text { There are written app ropriate, legally valid and up dated } \\
\text { agency Folicy Guidelines (policies and aroce dures) }\end{array}$ & 20 & 18 & 5 \\
\hline $\begin{array}{l}\text { A system reflecting channels of communication, both } \\
\text { internal and external, is available to ensure ade quate } \\
\text { functioning of the nursing agency }\end{array}$ & 20 & 18 & 12 \\
\hline $\begin{array}{l}\text { There is a human resource management programme (for } \\
\text { office staff and panel members) in accordance with } \\
\text { legislative reguirements }\end{array}$ & 20 & 21 & 15 \\
\hline $\begin{array}{l}\text { There is evidence of appropriate risk management to } \\
\text { ensure safety and quality of service deliwery by the nursing } \\
\text { agency }\end{array}$ & 20 & 21 & 19 \\
\hline $\begin{array}{l}\text { There is evidence of statistics and record keeping, in } \\
\text { accordance with legislative require ments, with reference to } \\
\text { the nursing agency's performance, staff, panel members } \\
\text { and clients }\end{array}$ & 20 & 22 & 17 \\
\hline There is a written quality improvement programme & 20 & 19 & 3 \\
\hline $\begin{array}{l}\text { There is evidence of a marketing strategy to balance free } \\
\text { enterprise, adhering to ethical principles and regulat ory } \\
\text { neguirements }\end{array}$ & 22 & 22 & 18 \\
\hline Average Content Validity Index & 21,15 & 21 & 15,76 \\
\hline
\end{tabular}

\section{Ethical considerations}

Informed consent and commitment to participate in the development of the standards was obtained from the participants and anonymity of validators was ensured.

\section{CONCEPTUAL FRAMEWORK}

During the initial workshop, the domain experts (nursing agency managers) developed the following framework for nursing agency standards: agency strategic framework, licensing, general governance/management, financial management, contracts, affiliation and co-operation, policies and procedures, communication, human resource management, risk management, statistics and record keeping, quality improvement and marketing of the agency.

\section{Strategic framework}

A nursing agency is a private business and should reflect the principles of good governance. This implies that the nursing agency should have a relevant written strategic/business plan, reflecting the principles of strategic planning in relation to a mission statement, formulation of strategic goals and supported by an operational plan, based on the environmental analysis (Muller, 1998:144-145).

\section{Licensing of the nursing agency}

Nursing Agencies are regulated by the South African Nursing Council in terms of the Nursing Act (South Africa, 1978, as amended) and the subsequent regulations. This implies that the nursing agency should comply with the licensing requirements, as well as the organisational and administrative requirements in accordance with the relevant regulation. The nursing agency is furthermore, legally obliged to comply with the financial regulations of the country in relation to financial management (Coopers \& Lybrand, 1998; South Africa, 1962; South Africa, 1985; South Africa, 1991).

\section{The principles of good business governance}

The nursing agency is managed in accordance with the principles of good business governance (Coopers \& Lybrand, 1998), as well as within the professional-ethical and legal framework of the South African nursing profession (South Africa, 1978, as amended) and the regulated health care environment in relation to the various legislation applicable.

\section{Financial management of the nursing agency}

Adequate and relevant financial management of the nursing agency as a business enterprise, is a very important dimension of excellence. Not only must the nursing agency comply with the principles of corporate governance with regard to accounting and financial responsibilities of a company (Coopers \& Lybrand, 1998), but they must also comply with the financial legislation of the country and the prin- 
ciples of fair labour practice with regard to their staff and panel members (South Africa, 1962; South Africa, 1978; South Africa, 1985; South Africa, 1995; South Africa, 1997).

\section{Contractual agreements between the nurs- ing agency and staff, panel members and clients}

A nursing agency enters into a complicated working relationship with the nursing/midwifery practitioners that render the nursing/midwifery care to the client, which can be an individual patient of a health care service provider, such as a hospital. It is therefore important to enter into contractual agreements with these service providers/clients in accordance with the legislative requirements and the principles of corporate governance. This implies a written agreement with each staff/panel member and with the various clients to ensure role clarification with regard to the different service and financial obligations and the mutual responsibilities in accordance with the principles of good business/corporate management (Coopers \& Lybrand, 1998).

\section{Affiliation and co-operation}

Affiliation and co-operation with relevant organisations could not only improve the quality of service delivery by the nursing agency, but also ensure continuity of service delivery. The Association of Nursing Agencies in South Africa could facilitate this process of quality improvement and sustainable service delivery to improve and sustain the image of nursing agencies in South Africa.

\section{Agency Policy Guidelines}

The cornerstone of quality in any organisation is to have written policies, procedures and guidelines in accordance with the principles of best practice - to have written standards (structure, process and outcome) that reflect the core business of the organisation (Muller, 1998:237-282). It is therefore important for the nursing agency to facilitate quality service delivery by means of relevant Agency Policy Guidelines in relation to the type of nursing and midwifery care rendered, the various human resource related interactions, as well as dimensions of professional conduct by the panel members (Government Notice R32, 1964, as amended).

\section{Communication}

The nursing agency should have a formal communication system to ensure adequate internal and external communication in the interest of nursing/ midwifery care and service delivery to its clients. Not only should the lines of communication be clearly delineated, but there should be evidence of reliable and continuous internal and external communication systems and networks to facilitate quality care and service delivery (Muller, 1998:263288).

\section{Human resource management}

Human resource management should be in accordance with the legislative requirements of the country, as well as in accordance with the principles of good business governance. This entails a human resource management strategy in relation to staffing, utilisation of staff, continuous professional development and fair labour practices (Muller, 1998:299-352).

\section{Risk management}

The nursing agency should display evidence of appropriate risk management to ensure safety and quality of service delivery in accordance with the legislative requirements and the principles of good business governance in South Africa (Muller, 1998:259-260).

\section{Statistical analysis and record keeping}

The nursing agency's credibility is dependent upon 
statistical analysis and record keeping with reference to its core business and performance. There should therefore be evidence of statistics and record keeping, in accordance with the legislative requirements (Government Notice R32, 1964; Muller, 1998:246-261), with reference to the nursing agency's performance, staff, panel members and the clients.

\section{Quality improvement programme}

Service delivery by the nursing agency could be to an individual patient and to a health care service provider. A quality improvement programme for home-based nursing/midwifery care is therefore important, reflecting the principles of quality improvement as described by Muller (1998:242-262). When the panel members are allocated to a health care service provider, such as a hospital, the nursing agency is also responsible for ensuring that this panel member complies with the principles of quality improvement within this health care service in relation to infection control, respect of patient rights, negative incident monitoring and continuity of care.

\section{Marketing strategy}

The nursing agency should display ethical behaviour when marketing the nursing agency, in accordance with the principles of good business governance in South Africa and in accordance with the professional-ethical and legal framework of the nursing profession as stipulated in the Nursing Act (South Africa, 1978, as amended) and the relevant regulations in this regard.

\section{RESULTS}

The results are presented in relation to the sample realisation, the process of standard formulation and the final standards/criteria. The Content Validity Index (CVI) obtained for the standards are summarised in table six.

\section{Sample realisation}

A total of 22 nursing agency members participated in the developmental and quantification phases (see table one). Most of these participants ( $\mathrm{N}=17)$ were general managers of the nursing agency responsible for the overall management of the agency, whilst four participants held the post of nursing service manager within the nursing agency. This type of distribution was dependent on the size of the agency as well as the principle of decentralisation countrywide. During the quantification phase, the participants were asked to list their responsibilities within the nursing agency. Examples of their main responsibilities to confirm their expertise, are quoted: "Overall management and allocation of panel members"; "Director and marketing of the nursing agency"; "Responsible for the overall management of the nursing agency at head office level as well as the other branches"; "Overall management, training and development as well as public relations"; "Implementation and control of the nursing agency's standards and quality"; "Management of a branch"; "Visiting matrons, unit sisters and hospital managers"; "Nursing management, training and education; public relations"; "Algehele beheer oor die agentskap, bestuur van fondse, personeel en kantoor"; "Total management and allocation of panel members"; "Project manager Natal branch"; "Occupational health, Primary health and home health care"; "Director of the agency - not day-to-day management."

Six different provinces were represented (see table two for the distribution figure) of which Gauteng Province reflected the highest representation $(\mathrm{N}=14)$. This could be attributed to the fact that Gauteng had the most nursing agencies and that the workshops were held in Pretoria. Most of the nursing agency members $(\mathrm{N}=14)$ hold a Diploma as the highest qualification (refer to table three). A few $(\mathrm{N}=6)$ hold a $\mathrm{B}$-degree and two participants reflected a masters degree as the highest qualification. Four of the general managers are not regis- 
tered nurses. Most of them ( $\mathrm{N}=17)$ have been involved in the management of a nursing agency for five years or less (see table four).

\section{The process of standard formulation}

A total of 13 standards were drafted by the four working groups (first draft) and refined by the researcher and the elected core group (second draft). These standards were prepared for validation purposes and exposed to the validators $(\mathrm{N}=22)$ during the workshop in June 2000. All the main standards were declared as relevant and therefore approved as valid (see table six). A total of three criteria were declared invalid (having obtained a CVI rating of less than 18). As far as clarity is concerned, 25 criteria were reformulated to enhance clarity and logical coherence. It was decided to delete "ANASA" from standard 6.2 in relation to affiliation to make provision for freedom of association. It is, however, significant to note that some of the standards (see table six) and many of the criteria do not reflect reality in that they are not yet implemented in existing nursing agencies. The CVI ratings on relevance, clarity and reality are reflected in table six.

The third set of draft standards and criteria were prepared for a final consensus debate with the relevant stakeholders in August 2000 (see table five). During this debate a few recommendations were made in relation to the changing of the numerical order of two criteria, the combination of two criteria and a few editorial/grammatical changes. The standards were accepted and appreciation was expressed for the hard work resulting in a quality control instrument. Due to the fact that the South African Nursing Council (SANC) representatives could not attend this workshop, the ANASA Executive Committee made an appointment with them in December 2000 and discussed/confirmed the standards with them. The final set of standards was prepared in the form of an evaluation guide/instrument with relevant decision-making rules for the surveyors. Pilot testing by means of a "moc survey" followed in November 2000. It is envisaged that these standards/instrument will be utilised by ANASA for empowerment purposes and by the South African Nursing Council for accreditation (of nursing agencies) purposes.

\section{STANDARDS FOR NURSING AGEN- CIES}

The final set of standards and criteria are presented in relation to the dimensions of excellence within the context of a nursing agency in South Africa.

\section{Agency strategic framework}

1. The nursing agency is managed as a business enterprise ensuring quality nursing/midwifery service delivery to clients:

1.1 There is a written strategic/business plan

1.2 The strategic plan reflects the current/ relevant legislative requirements

1.3 There is a written mission statement based on ethical-professional and realistic principles

1.4 The external and internal environmental analysis (SWOT: strengths, weaknesses, opportunities and threats) is described

1.5 The long and short-term goals are stated

1.6 There is an operational plan for the attainment of the goals/objectives with evidence of evaluation of the attainment of these goals/objectives at the end of the stated time frame

1.7 There is evidence of consistency/ compatibility with the strategic plan in the delivery of the nursing service provided by the nursing agency

\section{Licensing of the nursing agency}

2. The nursing agency responsible for 
temporary or permanent placements is appropriately licensed with the regulatory bodies

2.1 The current South African Nursing Council agency license is displayed

2.2 There is evidence of registration certification from the South African Revenue Service (SARS) with regards to VAT; SITE/PAYE and Skills Development

2.3 There is evidence of registration certification with the Regional Services Council

2.4 There is evidence of registration with the Compensation Commissioner

2.5 There is evidence of registration certification with the Department of Labour if the agency undertakes permanent placements

2.6 There is evidence of current membership with a professional organisation/quality institute who acts as the facilitator of quality improvement

2.7 The certificate of registration as closed corporation/company/trust is displayed

\section{Nursing agency management}

3. The nursing agency is managed in accordance with the standards of good business governance (policies/ procedures/protocols/codes)

3.1 There is a written organisational structure (organogram) delineating the positions and lines of communication of managerial and office staff

3.2 The person managing the allocation of panel members is currently licensed with the South African Nursing Council as a registered nurse/midwife

3.3 The person responsible for the allocation of panel members reports directly to the nursing agency management

3.4 There is access to legislation/Acts, Regulations and national policies in accordance with the current professionalethical and legal requirements on at least the following:

3.4.1 South African Constitution: Fundamental Human Rights

3.4.2 Nursing Act

3.4.3 Relevant nursing regulations

3.4.4 Health Care Act

3.4.5 Human Tissue Act and Blood Regulations

3.4.6 Medicines Act and Regulations

3.4.7 Child Care Act

3.4.8 Occupational Health and Safety Act

3.4.9 Compensation for Occupational Injuries \& Diseases Act

3.4.10 Labour Relations Act

3.4.11 Basic Conditions and Employment Act

3.4.12 Employment Equity Act

3.4.13 Skills Development Act

3.4.14 Patient Charter

3.4.15 Relevant health care-related Acts/ policies applicable to the specific health care service

3.4.16 Mental Health Act

3.4.17 Choice on Termination of Pregnancy Act

3.4.18 Sterilisation Act

3.4.19 Births and Deaths Act

\section{Financial Management}

4. The financial manager is responsible for the preparation and integrity of financial statements

4.1 There is evidence of sound financial management in accordance with the principles of good business governance

4.2 There is evidence of accounting and administration control with appropriate reconciliation

4.3 Financial procedures are executed in accordance with regulatory (SANC) requirements, including agency commission and Council licence fees

4.4 Financial/company procedures are 
executed in accordance with legislative requirements (e.g. salary/wage structure, UIF, VAT, Workman's Compensation and PAYE)

4.5 There is evidence of financial record keeping in relation to at least the following:

4.5.1 Pay register reflecting monthly gross salaries earned and all deductions and additions stipulated e.g. commission, leave, sick leave, public holidays and Sundays

4.5.2 Accounts to clients

4.5.3 Receipts to clients

4.5.4 Receipts of payment from Department of Inland Revenue for Tax deducted from panel members

4.5.5 Receipts from Department of Inland Revenue for Vat

4.5.6 IRP5/IT3 issued annually to Panel Members

4.5.7 IRP 30 Exemption Certificate for Employees Tax

4.5.8 Annual financial Statements of the Agency

4.5.9 Inspection Certificate from the Department of Inland Revenue, if issued

4.5.10 Receipts from Regional Services for monthly payments made

4.5.11 Annual Receipt from Compensation Commissioner

4.5.12 Receipts on equipment rental/other contractual agreements

4.6 The financial/nursing manager prepares and negotiates the nursing agency budget

4.7 There is evidence that the financial/nursing manager partakes in the implementation of the budget

4.8 There is evidence of continued and timeous monitoring of income and expenditure through statistical analysis, available for perusal at any time by concerned bodies i.e. auditors, evaluators, investigating committee for the South African Nursing Council

4.9 There is evidence of reasonable indemnity/ liability insurance for the nursing agency
4.10 There is evidence of professional bodies executing certain duties if these are not done internally e.g. bankers, accountants, auditors, attorneys and management consultants ensuring the professional integrity of nursing agencies

4.11 There is evidence of bad debt management

4.12 There is evidence of a timeous remuneration of panel members

4.13 There is evidence of adequate financial resources to ensure timeous payment of panel members in accordance with agreements

4.14 There is a support system that allows for the active/pro-active management of poor payment by clients

\section{Contracts}

5. There is evidence of contractual agreements between the Nursing Agency and office staff, panel members, as well as clients and other relevant stakeholders

5.1 There is a written service contract between the agency and office staff/panel members in accordance with the legislated basic conditions of employment and other labour law

5.2 There is a written contract between the agency and the client reflecting at least the following:

5.2.1 service obligations

5.2.2 financial obligations

5.2.3 mutual responsibilities

5.3 There are written contracts (when applicable) on the following:

5.3.1 renting of premises and/or equipment

5.3.2 outsourced services

5.4 The contract/s are approved by credible legal consultants/organisation

5.5 The contract/s are filed and stored appropriately

5.6 There is a written and user-friendly enquiry 
process available to clients and panel members

\section{Affiliation and co-operation}

6. The agency seeks affiliation and cooperation with relevant organisations for the improvement of service delivery

6.1 The management displays knowledge on the Board of Healthcare Funders and their scale of benefits pertaining to home nursing

6.2 There is proof that the nursing agency seeks accreditation by a credible external organisation to confirm sustainable/ ongoing quality service delivery

\section{Policies and procedures}

7. There are written appropriate, legally valid and updated Agency Policy Guidelines (policies and procedures):

7.1 The policy guidelines reflect the main clinical business of the nursing agency

7.2 There is a procedure manual (process standards/clinical guidelines) on relevant nursing/midwifery interactions for home nursing care when applicable

7.3 There are policies and procedures on human resource management on at least the following:

7.3.1 the management of grievances of office staff and panel members

7.3.2 disciplinary action

7.4 There are policies and procedures on occupational health and safety (e.g. needle stick injuries, injury on duty, etc.)

7.5 There are policies and procedures on dress code

7.6 There are policies and procedures on the placement of panel members

7.7 There are policies and procedures on a code of conduct

7.8 The policies and procedures are dated and signed
7.9 The policies and procedures are reviewed according to review dates and/or as required by legislation

7.10 The policies and procedures are appropriately indexed, filed and retrievable to facilitate accessibility by all staff and panel members

\section{Communication}

8. A system reflecting channels of communication, both internal and external, is available to ensure adequate functioning of the nursing agency

8.1 There is evidence of an organisation chart reflecting the lines of communication both internal and external

8.2 There is evidence of telecommunication systems

8.3 There is evidence of a customer service communication network to facilitate timeous and appropriate communication with nursing agency clients

8.4 There is a system to ensure adequate communication between management and staff

8.5 The publications from ANASA are available/accessible to update nursing agencies on relevant matters

\section{Human resource management}

9. There is a human resource management programme (for office staff and panel members) in accordance with legislative requirements

9.1 Staffing (recruitment, advertising, selection and appointment) of panel members and office staff is in accordance with the current labour legislation and professional-ethical and legal framework of the South African nursing profession

9.2 There is a recruitment strategy for panel members in accordance with the ethical 
principles of good business governance

9.3 There is a formalised selection and appointment system (standards: policies and procedures) in accordance with legislative requirements

9.4 Utilisation of office staff and panel members is in accordance with legislative requirements in relation to their abilities (knowledge, skills, values and attitudes), scope of practice and contracted agreements

9.5 The allocation of panel members is done according to the required nursing/ midwifery care in relation to the abilities (knowledge, skills, values, attitudes and experience) of the panel member in accordance with the legislated scope of practice

9.6 There is a system of orientation/briefing of new office staff and panel members

9.7 There is a system of briefing of a panel member upon allocation to a client in relation to the relevant nursing/midwifery care requirements

9.8 There are written job descriptions and standards on expected performance for office staff and panel members

9.9 There is a continual professional/skills development programme for office staff and panel members in accordance with legislative requirements and professionalethical standards of the nursing profession

9.10 There is a performance appraisal/ evaluation system for office staff based on the standards of expected performance/job descriptions

9.11 There is a performance appraisal/ evaluation system for panel members, based on the expected standards of performance/job descriptions, with stipulated responsibilities of the nursing agency, client and panel member in this regard

9.12 There is evidence of appropriate feedback and training/empowerment to address deficiencies identified during performance appraisal/evaluation of office staff and panel members

9.13 There is evidence of fair labour practice in accordance with legislative requirements in relation to the management of grievances, disciplinary actions and/or dismissals

9.14 There is proof of Professional Indemnity Insurance by panel members prior to allocation/placement

\section{Risk management}

10. There is evidence of appropriate risk management to ensure safety and quality of service delivery by the nursing agency

10.1 There is a written risk management programme for the nursing agency, office staff and panel members in accordance with legislative requirements

10.2 There are adequate facilities to ensure consultation with office staff, panel members and other relevant stakeholders in relation to their constitutional rights (e.g. privacy)

10.3 The office environment is certified as safe in accordance with legislative requirements

10.4 There is proof of insurance for premises and public liability

10.5 Security measures are in place for the office staff of the nursing agency as well as panel members visiting the premises, in accordance with legislative requirements

10.6 There is proof of preparedness for a disaster (e.g. evacuation procedure, emergency/first aid kit and emergency contact numbers) in the nursing agency office

10.7 There is proof of 24-hour communication accessibility between placement officers, panel members and clients

10.8 If the nursing agency transports panel 
members to and from clients, there is proof that a safe and acceptable transport system is in place with adequate insurance

10.9 There is a pro-active/maintenance and replacement programme for relevant office equipment

\section{Statistics and record keeping}

11. There is evidence of statistics and record keeping, in accordance with legislative requirements, with reference to the nursing agency's performance, staff, panel members and clients

11.1 Records and relevant statistics are kept on home-based individual clients/patients in accordance with the legislative requirements by the South African Nursing Council

11.2 Records and appropriate statistics are kept on relevant health care organisations as clients

11.3 Relevant human resource management records and statistics are kept on office staff in accordance with labour legislative requirements

11.4 Relevant human resource management records and statistics are kept on panel members, in accordance with labour legislative and SANC requirements, on at least the following:

11.4.1 biographical and professional details on appointment

11.4.2 service contracts

11.4.3 on/off duty registers with proof of panel member confirmation

11.4.4 the credentials (qualifications, registered/ enrolment status and experience) of panel members in relation to designated allocations/placements by the nursing agency

11.4.5 the outcome of performance appraisal evaluation

11.4.6 continuous professional and skills development activities

11.4.7 grievances and disciplinary activities when applicable

11.4.8 quality improvement-related incidents and/ or activities

11.4.9 termination of services

11.4.10 other relevant conditions of employment activities

11.5 All records are stored and secured in archives for at least a five (5) year period

11.6 There is a system whereby office staff and panel member files are updated and managed with adherence to the principles of confidentiality

11.7 Monthly figures in respect of panel member placements and human resource management are available

11.8 There is a designated person responsible for maintaining monthly client-related and human resource statistics within the nursing agency

\section{Quality improvement}

12. There is a written quality improvement management programme

12.1 For home-based/individual nursing care

12.1.1 There are written standards/protocols for home-based/individual nursing care

12.1.2 There are written records of clinical care provided to patient

12.1.3 There is supervision of staff within scope of practice

12.1.4 There is evidence that the essential service component (24 hour service) of a nursing agency is accessible (to supply panel members at short notice)

12.2 Client satisfaction is monitored and dissatisfaction is appropriately addressed

12.3 There is a negative incident monitoring and management system (for both clinical and managerial activities) in place

12.4 There is evidence of appropriate remedial/ correctional action programmes when 
applicable

12.5 There is a system to ensure that panel members adhere to the infection control programmes of health care organisations/ nursing agency

12.6 There is a system to ensure that panel members adhere to the quality improvement standards of health care organisations/nursing agency

12.7 There is a system to ensure that patient rights (fundamental human rights and Patient Charter) are respected

\section{Marketing of the agency}

13. There is evidence of a marketing strategy to balance free enterprise, adhering to ethical principles and regulatory requirements

13.1 There is a written marketing strategy for the nursing agency

13.2 The relevant stakeholders of the nursing agency are identified

13.3 There is evidence that the nursing agency contributes towards the development and sustainability of the nursing profession's image (sponsorships/participation in continuous professional development activities and quality improvement)

13.4 The nursing agency adheres to the principles of good business governance and relevant ethical codes as a private organisation.

\section{CONCLUSIONS}

Standards for nursing agencies in South Africa were formulated. A very high Content Validity Index with reference to relevance and clarity of the standards and criteria was achieved which confirms a high level of content validity, as well as ownership by the nursing agency managers. Some standards and many criteria have, however, not yet been implemented as reflected in the Content Validity Index obtained in relation to reality. The researcher ex- perienced a very high level of commitment by the nursing agency managers during the series of workshops that were held that could impact positively on the implementation of the standards.

\section{RECOMMENDATIONS}

The following recommendations are made:

- Self-evaluation by the nursing agency managers by utilising the standards.

- That these standards be utilised by the South African Nursing Council for the licensing of nursing agencies and for continuous accreditation purposes.

- That ANASA acts as the official peer group to foster quality service delivery by nursing agencies in South Africa.

- Testing and continuous updating of the standards.

- Statistical determination of validity and reliability of the standards and criteria, as reflected in the final form of an evaluation guide/instrument.

\section{LIMITATIONS}

As only ANASA members were used during the development of the standards (during both the developmental and quantification phases), national representation of nursing agencies in South Africa cannot be claimed.

\section{Acknowledgements}

The management of ANASA and their members are hereby thanked for the opportunity to participate in the formulation of these standards. Mrs Nelouise Geyer (DENOSA) is also thanked for acting as convenor of the consultative sessions and workshops. The standards, reflected in the form of an evaluation guide, can be obtained from ANASA.

\section{REFERENCES}

BOOYENS, SW (Ed.) 1998: Dimensions of Nursing Management; second edition. Kenwyn: 
Juta.

BURNS, N \& GROVE, SK 1993: The Practice of Nursing Research. Conduct, Critique, \& Utilization; second edition. Philadelphia: WB Saunders.

COETZEE, L \& MULLER, ME 1995: Standards for nursing agencies. RAUCUR Interdisciplinary Academic Journal on Health, 1(1), July: 17-24. COOPERS \& LYBRAND COMPANY 1998: Corporate Governance. Being a director. A guide to your duties and responsibilities. Institute of Directors (unpublished).

GOVERNMENT NOTICE R32. 1964 (as amended): Regulations regarding the conditions under which the business of a nursing agency may be carried out. Pretoria: State Press.

LYNN, MR 1986: Determination and quantification of content validity. Nursing Research, 35(6), November/December 1986:382-385.

MULLER, ME 1990: Navorsingsmetodologie vir die formulering van verpleegstandaarde. Curationis, 13(3\&4), Desember 1990:49-55.

MULLER, ME 1998: Nursing Dynamics; second edition. Sandton: Heinemann.

SOUTH AFRICA 1962: Income Tax Act (no. 58 of 1962, as amended). Pretoria: State Press.

SOUTH AFRICA 1978: Nursing Act (no. 50 of 1978, as amended). Pretoria: State Press.

SOUTH AFRICA 1985: Regional Services Council Act (no. 109 of 1985, as amended). Pretoria: State Press.

SOUTH AFRICA 1991: Value Added Tax Act (no. 89 of 1991, as amended). Pretoria: State Press. SOUTH AFRICA 1995: Labour Relations Act (no. 66 of 1995, as amended). Pretoria: State Press.

SOUTH AFRICA 1997: Compensation for Occupational \& Injuries Diseases Act (no. 61 of 1997). Pretoria: State Press. 